\title{
Omnivory and resource - sharing in nutrient - deficient Rio Negro waters: Stabilization of biodiversity?
}

\author{
Ilse WALKER ${ }^{1}$
}

\section{ABSTRACT}

Amazonian biodiversity is notorious, this is also valid for the fauna of the mineral-deficient waters of the Rio Negro System. Some 25 years of research on the benthic fauna of Central Amazonian streams resulted in species-rich foodwebs with a high degree of omnivory within dense animal communities.

To exemplify the taxonomic range of omnivorous consumers, the detailed resource spectra of 18 consumer species, including Protozoa ( 2 species), Platyhelminthes (1 species), insects ( 2 species), fish (6 species) and shrimps (Decapoda, 7 species), associated primarily with the benthic habitats of Rio Negro tributaries, are presented. Special features of omnivory are characterized, and the importance of litter-decomposing fungi as essential energy input into the foodwebs is documented. It is shown that general omnivory-diverse omnivore consumers sharing most of the resource types- is a prevalent feature. The relevance of this general omnivory for the maintenance of biodiversity is discussed.

KEY WORDS: Amazonas, Rio Negro, Omnivory

\section{Omnivoria e repartição de recursos em águas pobres em nutrientes da Bacia do Rio Negro}

\begin{abstract}
RESUMO
A biodiversidade do Amazonas é notório e isto também é válido para as águas pobres em nutrientes da bacia do Rio Negro. Uma pesquisa de 25 anos da fauna béntica de igarapés da Amazônia Central resultou em redes alimentares caraterizadas por alta diversidade de espécies, por intensa omnivoria e por alta densidade populacional.

Para demonstrar a generalidade taxonômica de omnivoria no bentos dos igarapés, são apresentados as listas de presas / recursos de 18 espécies de consumidores, sendo Protozoa (2 epécies), Platyhelminthes ( 1 espécie), insetos (2 espécies), peixes (6 espécies) e camarões (Decapoda, 7 espécies). Diferentes categorias de omnivoria são apresentados, e a importância de fungos decompositores da liteira submersa como input básico de energia nas redes alimentares é demonstrada. É prevalente a omnivoria geral, sendo que as diferentes espécies omnívoros estão utilizando os mesmos recursos. Considera- se a relevância desta omnivoria geral para a manutenção da biodiversidade.
\end{abstract}

PALAVRAS-CHAVE: Amazonas, Rio Negro, Omnivoria

${ }_{1}$ Instituto Nacional de Pesquisas da Amazônia (INPA), Coordenação de Pesquisas em Ecologia (CPEC), Caixa Postal 478, 69011-970, Manaus (AM). E-mail: iwalker@inpa.gov.br 


\section{INTRODUCTION}

The prevalence of omnivory in the aquatic fauna principally also of the benthic communities of streams and rivers - is amply documented for different geographic and climatological regions. Thus for shrimps (Decapoda) in Japan (Usio el al 2002), New Zealand (Parkyn et al 2001) and the Amazon (Kensley and Walker 1982); for fish in the Amazon (Goulding et al 1988), in the Midwestern USA (Evans-White et al 2001), in Costa Rica (Pringle and Hamazaki, 1998) and in Australia (Arthington 1992); for aquatic insect larvae, such as Odonata (Woodward and Hildrew, 2001) and Plecoptera in England (Lancaster et al 1995), to mention some of the more recent examples.

Omnivory is of fundamental importance for the dynamics of the trophic structure, and hence, of general population dynamics in the respective ecosystems. In the measure consumers are omnivorous, competition presumably intensifies, as suggested by Woodward and Hildrew (2001). The counter-argument is, that omnivory stabilizes communities, because consumers may switch to alternative resources if one particular resource species gets rare, hence, there is a chance for this species to recuperate. The problem of these two conflicting arguments is of particular interest as regards the benthic fauna of high biodiversity in mineraldeficient waters, as documented for Central Amazonian forest streams (Walker 1995), and will be discussed in the last section of this article.

"Omnivore" in the strict verbal sense means "who eats everything that is edible". In the traditional eclogical sense, omnivores are animals that are herbivores as well as carnivores. For the purpose of foodweb studies, Pimm and Lawton (1977) defined "omnivory" as feeding on more than one trophic level. In this sense, an obligatorily carnivorous fish that feeds on odonata and chironomid larvae is an omnivore, because dragonfly larvae also feed on chironomids. In fact, the situation is much more complicated, because resource uptake may be a function of the life cycle of the consumers (Pimm 1991), of environmental periodicities, such as annual inundation cycles in Amazonian river basins for example, and of unpredictable changes of microhabitats as a consequence of consumer or resource dislocations. The question is, whether omnivory in the strict verbal sense, that is "general omnivory" also exists, a situation that would intensify the problem of ecosystem stability.

Analysis of the benthic, litter-dwelling communities of Central Amazonian forest streams between 1977 and 1987 resulted in the presentation of the general foodweb structure of the micro/mesofauna (Walker 1985) and of the macrofauna (Walker 1987) in Amazonian streams. As these streams drain mineral-poor latosols and podsols (Chauvel et al 1987) in areas of closed high-canopy forest, phytoplankton is very poorly represented. The food chains start essentially with the litterdecomposing fungi, an essential component of the benthic habitats of forest streams, as also shown by Padgett (1976) and Methvin and Suberkropp (2003) for other regions.The fungi are ingested by micro- and macroinvertebrates, and both foodwebs are predominantly omnivore. However, omnivory is proven then only, when it refers to single consumer species, while in more general foodwebs related species are joined in a single position at a given trophic level. In this communication, therefore, the resources of single consumer species are listed. In order to highlight the generality of omnivory in these Amazonian streams, the consumer species include protozoa and platyhelminths, which were observed in vivo in multi-species, quasi natural laboratory cultures of the aquatic microfauna, as well as odonata, shrimps and fish that were collected in the field for examination of their stomach content. The list of consumer-specific resource items allows for identification of the category of omnivory that is realized by the respective consumers (herbivory/carnivory, different trophic levels, general omnivory), and furthermore, it is indicative for the basic, primary energy input in terms of $\mathrm{C}_{3}$ - or $\mathrm{C}_{4}$ - plants as determined by carbon isotope $\left({ }^{13} \mathrm{C}\right)$ analysis (phytoplankton with lowest ${ }^{13} \mathrm{C}$ values as compared with higher plants; Forsberg et al 1993).

\section{AREAS OF COLLECTION, MATERIAL AND METHODS}

All consumer organisms presented in Tables 1, 2, 3 and 4 were collected in acid, mineral-poor blackwaters of the Rio Negro Basin (Sioli 1984), mostly in smaller rivers in the vicinity of Manaus, $\mathrm{pH}-$ values varying from $-3-5$, and conductivity from $-8-40 \mu \mathrm{S}_{20} / \mathrm{cm}$ (Walker 1995).

\section{MICROFAUNA}

Collection and maintenance. The ciliate Dileptus cf anser (Holotricha) appeared in December 1976 in samples taken within floating grasses along the margin of one of the islands of the "Archipélago das Anavilhanas", a complex of hundreds of islands in the Rio Negro, which starts some $55 \mathrm{~km}$ upriver from Manaus (Walker 1978). The roots were vigorously shaken within a bucket filled with river water. The detached fauna was established in the laboratory in sub-samples of $100 \mathrm{ml}$ of the original mixture of the organisms of the bucket- sample, and pellets of bakers yeast (Saccharomyces) and fresh river water were periodically added to keep the foodweb going. Furthermore, pieces of submerged litter leaves with their attached mesofauna, collected in litterbanks of the blackwater forest stream Tarumã-Mirím (entering the Rio Negro ca $25 \mathrm{~km}$ west of Manaus) were occasionally added, in order to increase the number of potentially interacting species. One of these later appearing species (1977), associated with litter fragments, was the tiny free-living flatworm Stenostomum sp (Rhabdocoela, 
Table 1 - Patterns of predation of the Protozoa Dileptus cf anser, and Stentor sp, and of the flatworm Stenostomum sp, as observed in vivo in laboratory cultures.

\begin{tabular}{|c|c|c|c|}
\hline \multirow{4}{*}{ Prey } & \multicolumn{3}{|c|}{ Consumers/Predators } \\
\hline & \multicolumn{2}{|c|}{ Protozoa, Ciliata } & \multirow{2}{*}{$\begin{array}{c}\text { Platyhelminthes } \\
\text { Catenulidae }\end{array}$} \\
\hline & Holotricha & Spirotricha & \\
\hline & Dileptus cf anser & Stentor sp & Stenostomun sp \\
\hline Bacteria & + & + & + \\
\hline \multicolumn{4}{|l|}{ Algae } \\
\hline Diatomeae & & + & \\
\hline Chilomonas & & + & + \\
\hline Fungi, unspecif. & & + & \\
\hline Saccharomyces & + & & + \\
\hline Saprolegnia & & & + \\
\hline \multicolumn{4}{|l|}{ Rhizopoda } \\
\hline Vahlkampfia & + & & \\
\hline Arcella & + & + & + \\
\hline Diffugia & & & + \\
\hline Euglyphidae & & + & \\
\hline \multicolumn{4}{|l|}{ Ciliata } \\
\hline Paramaecium & & + & \\
\hline Peritricha & & + & \\
\hline Nematoda & + & & \\
\hline \multicolumn{4}{|l|}{ Rotifera } \\
\hline Euchlanidae & + & + & + \\
\hline Philodinidae & + & & \\
\hline Gastrotricha & + & & \\
\hline \multicolumn{4}{|l|}{ Micro - Crustacea } \\
\hline Ostracoda & & & + \\
\hline Copepoda & & & + \\
\hline Cladocera & & & + \\
\hline Detritus & & & + \\
\hline (plant + animal) & & & \\
\hline
\end{tabular}

Table 2 - Prey of two species of Odonata larvae as established by stomach dissection; given are number of predators with ingested prey types. ? algae ingestion is questionable (see explanation in text).

\begin{tabular}{lcc}
\hline & \multicolumn{2}{c}{ Odonata } \\
\hline \multirow{2}{*}{ Prey } & Zygoptera Ischneura sp & Anisoptera Aeschnosoma sp \\
\cline { 2 - 3 } Algae & & $1 ?$ \\
Thecamoebae & & 1 \\
Nematoda & & 1 \\
Rotifera & 1 & \\
Cladocera & 1 & 3 \\
Oligochaeta & & 9 \\
Acari & 2 & \\
Collembola & 3 & 2 \\
Ephemeroptera & 4 & 5 \\
Plecoptera & 2 & 1 \\
Trichoptera & & 2 \\
Odonata & & 2 \\
Hemiptera & & 4 \\
Chironomidae & 10 & 8 \\
Fish & & 2 \\
\hline
\end{tabular}

Catenulida), while the ciliate Stentor sp. (Spirotricha) was found in 1979 in samples of mesozoa from the blackwater forest stream Igarapé da Cachoeira, one of the headwater streams of the Rio Cuieiras which joins the Rio Negro some 70km up-river from Manaus (Walker 1985).

These mixed, "quasi- natural" cultures were kept under observation for more than two years. The feeding behaviour of this mesofauna was observed in vivo under binocular microscopes (10 - 250x magnifiaction).

\section{MACROFAUNA}

Sampling areas: All shrimps (Decapoda) and the majority of the fish were collected in the small (ca $35 \mathrm{~km}$ long) blackwater forest stream Tarumã- Mirím, a northern tributary that joins the Rio Negro ca $25 \mathrm{~km}$ up-river from the Manaus harbour. Including the meanders, river length almost triplicates. Some of the fish were collected on an excursion along the Rio Negro (10. Sept. - 3. Oct. 1999), in the lower courses of the affluents Rio Uaupés, Rio Curicuriarí and Rio Marié (all 9 Copella, half of the Elachocharax and of 
Table 3 - Resource spectra of the six fish species Elachocharax pulcher, Hyphessobrycon sp, Copella sp (Characidae), Apistogramma cf regani, Mesonauta insignis (Cichildae), and Nemuroglanis sp (Heptapteridae). Given are number of fish with ingested resource type. № ind. = total number of dissected individuals. Size in $\mathrm{mm}=$ standard length of fish. *For specification of detritus see text. * 0 wing to the advanced stage of decomposition, distinction between ephemeropteran and plecopteran larvae was uncertain in some cases.

\begin{tabular}{|c|c|c|c|c|c|c|}
\hline \multirow{2}{*}{ Consumers } & \multicolumn{3}{|c|}{ Characidae } & \multicolumn{3}{|c|}{ Cichlidae } \\
\hline & E.pulcher & Hyph.sp & Copella.sp & A. cf regani & M. insignis & Nemur. sp \\
\hline No ind. & 19 & 11 & 9 & 18 & 16 & 15 \\
\hline Size, mm & $11-21$ & $20-30$ & $8,5-23$ & $12-28$ & $11-34$ & $24-35$ \\
\hline Detritus, unspecif.* & & & & 1 & & \\
\hline Plants/roots & 2 & 2 & & 4 & & 1 \\
\hline Periphyt. unsp. & & 5 & & & 1 & \\
\hline Algae, Diatomeae & 1 & & 1 & 1 & & \\
\hline Thecamoebae & & & 1 & 3 & & 1 \\
\hline Oligochaeta & & 1 & & 6 & 1 & 1 \\
\hline \multicolumn{7}{|l|}{ Crustacea } \\
\hline Ostracoda & 3 & 2 & & 1 & & \\
\hline Copepoda & 3 & & 2 & 2 & & 6 \\
\hline Cladocera, unsp. & 6 & 10 & 5 & 8 & 8 & 3 \\
\hline Daphnidae & & 3 & 1 & & 2 & \\
\hline Macrothricidae & 2 & 1 & & & & \\
\hline Decapod larvae & & & & 2 & & \\
\hline \multicolumn{7}{|l|}{ Insecta } \\
\hline Collembola & 2 & & & 1 & & \\
\hline *Ephemeropt/Plecopt. & 5 & 4 & 3 & 5 & 4 & 7 \\
\hline Trichoptera & & & & 3 & & \\
\hline Odonata & & & & & 2 & \\
\hline Hemiptera, unsp. & & & & & 1 & \\
\hline Corixidae & 1 & & 1 & & & 1 \\
\hline Naucoridae & & & & 1 & & \\
\hline Coleopt. larvae & & & & 1 & 1 & \\
\hline Diptera, unsp. & & 2 & & 1 & 4 & 1 \\
\hline Chironominae & 9 & 4 & 2 & 9 & 9 & 3 \\
\hline Tanypodinae & 6 & 1 & & 3 & 1 & 4 \\
\hline Ceratopogonidae & 2 & & & 1 & & \\
\hline Hymenoptera adult ants & & 1 & 1 & & 2 & $1 ?$ \\
\hline Acarina & 4 & 1 & 1 & & 2 & 1 \\
\hline Eggs & 1 & & 1 & & & \\
\hline
\end{tabular}

Table 4 - Resource spectra of shrimp species (Decapoda, Natantia) collected in undisturbed, Central Amazonian forest streams (vicinity of Manaus). Given are number of shrimps with ingested resource types. $\mathrm{Nr}=$ total number of dissected individuals per species. $\mathrm{ad}=$ adults; juv. $=$ juveniles. ${ }^{*}$ Whether nematodes are parasites or prey is uncertain. (Kensley and Walker 1982; Euryrhynchus: Walker 2001 and new data, years 2000 and 2006)

\begin{tabular}{|c|c|c|c|c|c|c|c|c|c|}
\hline \multicolumn{10}{|c|}{ Decapod consumer species } \\
\hline \multirow{4}{*}{ Stomach content } & & \multicolumn{2}{|c|}{ Euryrhynchus } & \multicolumn{3}{|c|}{ Macrobrachium } & \multicolumn{2}{|c|}{ Pseudopalaemon } & \multirow{3}{*}{$\begin{array}{c}\text { Palaemonetes } \\
\text { carteri }\end{array}$} \\
\hline & & amaz. & burch. & & & inpa & chryseus & amaz. & \\
\hline & & & & juv. & $\mathrm{ad}$. & & & & \\
\hline & $\mathrm{Nr}$ & 27 & 29 & 25 & 25 & 25 & 25 & 25 & 10 \\
\hline Plantmaterial & & 12 & 4 & 6 & 6 & 6 & 6 & 4 & 3 \\
\hline Fungi & & 13 & 3 & 12 & & 15 & 11 & 13 & 8 \\
\hline Algae & & 2 & & 3 & & 1 & 14 & 6 & 7 \\
\hline Thecamoebae & & 3 & 2 & 2 & 1 & 3 & 1 & & \\
\hline Nematoda * & & 1 & & & & 1 & & 1 & \\
\hline Rotifera & & 2 & & 1 & & & & 4 & 1 \\
\hline
\end{tabular}


Table 4 - Continuation.

\begin{tabular}{|c|c|c|c|c|c|c|c|c|c|}
\hline \multicolumn{10}{|c|}{ Decapod consumer species } \\
\hline \multirow{4}{*}{ Stomach content } & & \multicolumn{2}{|c|}{ Euryrhynchus } & \multicolumn{3}{|c|}{ Macrobrachium } & \multicolumn{2}{|c|}{ Pseudopalaemon } & \multirow{2}{*}{$\begin{array}{c}\text { Palaemonetes } \\
\text { carteri }\end{array}$} \\
\hline & & amaz. & burch. & & & inpa & chryseus & amaz. & \\
\hline & & & & juv. & $\mathrm{ad}$. & & & & \\
\hline & $\mathrm{Nr}$ & 27 & 29 & 25 & 25 & 25 & 25 & 25 & 10 \\
\hline Oligochaeta & & 7 & & 7 & & 14 & 8 & 11 & 4 \\
\hline \multicolumn{10}{|l|}{ Crustacea } \\
\hline Cladocera & & 4 & 9 & 4 & & 2 & 1 & 4 & 2 \\
\hline Ostracoda & & & 1 & & & & & 1 & \\
\hline Copepoda & & 2 & & & & & & 4 & \\
\hline Decapoda & & & & & 1 & 6 & & 3 & \\
\hline Insecta, unsp. & & & 9 & & & & & & \\
\hline Odonata & & & & 2 & 2 & 3 & & & \\
\hline Trichoptera & & 1 & & 1 & & 2 & 2 & & \\
\hline Plecoptera & & & & 4 & & 7 & 2 & 9 & \\
\hline Ephemeropt. & & 2 & 4 & 3 & & 2 & 3 & 6 & \\
\hline Hymenopt.,ad & & & & & 10 & & & & \\
\hline Coleopt., ad. & & 4 & & 7 & 1 & 13 & 10 & 6 & 2 \\
\hline Diptera, unsp. & & 2 & & & 1 & 2 & & & \\
\hline Chironomidae & & 5 & 3 & 7 & 7 & 9 & 4 & 12 & \\
\hline Acarina & & 5 & & 4 & 1 & 1 & 5 & 2 & \\
\hline Tardigrada & & 1 & & 2 & & & 2 & 2 & \\
\hline Eggs (invertebr.) & & 1 & & & 1 & 1 & 3 & 1 & \\
\hline Fish & & & 1 & 1 & 1 & & & & \\
\hline
\end{tabular}

the Apistogramma specimens, and 2 Mesonauta; Tab. 3). The objective of this excursion was fish taxonomy, hence, only a limited number of the more frequent species was available for dissection. A further reason for limited numbers of consumers listed in Tabs. 3 and 4 (fish and shrimps) is the high frequency of empty stomachs, which may imply seasonal feeding periods (Walker, in preparation).

The data on the Odonata (Tab.2) are extracted from Walker (1987), which presents the general foodweb of the benthic fauna of the two Central Amazonian blackwater streams Tarumã- Mirím and Rio Cuieiras (see above). Ischneura sp. (Zygoptera) and Aeschnosoma sp. (Anisoptera) were two of the most frequent species with analysed stomach contents, and hence, were chosen as examples for Tab. 2 .

In all these rivers, the habitats sampled was the submerged leaf litter in the areas of the annually inundated "igapó"-forest, that is, litterbanks in the meanders of the river channel during lowest-water periods (Oct - Jan), and the inundated forest floor and litterbanks during rising and falling water levels, and furthermore, the shrubby edges of the stream channels with floating roots and occasional waterplants.
Methods: The Odonata larvae, shrimps and fish were collected with handnets of ca 8 liter volume $\left(1 \mathrm{~mm}^{2}\right.$ mesh size) which were pushed underneath the litter layer and then quickly lifted out of the water. The animals were removed by hand and stored in 70\% alcohol. In case of collection within the inundated marginal vegetation (low shrubs and occasional water plants), the handnet was placed underneath the roots and branches and vigorously shaken before removing the net from the water. In the laboratory, the animals were dissected under the low-power binocular, the stomachs/ventricles were openend, and the contents examined under appropriate higher magnification. Detritus in the gut behind the ventricle was not considered, because the ingested prey organisms may be in an advanced stage of digestion, thus simulating detritus.

\section{IDENTIFICATION OF MATERIAL}

In the Amazon, the consumer categories Odonata and fish are extremely species- rich, and different larger river basins are practically isolated regions. Taxonomic identification to the species level is therefore most of the time impossible.To illustrate this general amazonian situation: Motta-Bührnheim \& Cox-Fernandez (2003) analysed the fish assemblages of 
three headwater streams of the River Urubu which enters the Amazon ca $180 \mathrm{~km}$ East of Manaus: of the total of 22 fish species collected, 9 species could not be identified to the species level. With the exception of the shrimps (Tab. 4, extracted from Kensley and Walker 1982 and from Walker 2001), identification to the level of species was therefore not possible. Close examination of the dissected animals, though, allowed for the conclusion, that the respective group belonged to a single species within the respective Genus. The identification of the fish in Table 3 follows the recent classification by Reis et al (2003).

Identification of the ingested prey organisms is still more problematical, because, in general, the material is triturated and/or in an advanced stage of digestion. Hence, prey organisms were in most cases identified on the levels of Order or Family only.

The category of Detritus was avoided wherever possible, because triturated animals or plant tissues can be categorized as such. Some particles of organic sediments (detritus in the strict sense) usually enter the stomach with prey catch, and there are the remains of the gut contents of the prey organisms: these two categories of particles are not indicative of "feeding on detritus". For the same reasons, the contents of the digestive tract behind the stomachs of fish and behind the proventriculi of the arthropods were not included in the data presented. Only if a considerable volume of the stomach/ventriculus was filled with organic detritus, was the observation categorized as "detritus feeding". In fact, only one such case was noted (Table 3).

\section{RESULTS: CONSUMER-SPECIFIC PATTERNS OF OMNIVORY}

\section{THE PROTOZOA AND PLATYHELMINTHS (TABLE 1.)}

Both protozoans ingest prey ranging from Procaryota (Bacteria), Fungi, to metazoa (Rotifera). The relatively large size of these two ciliates ( $0,4 \mathrm{~mm}$ length) allows for the ingestion of complex metazoans, for instance, one Dileptus was found with two ingested rotifers. Tackling a nematode, though, was unsuccessful: the much longer worm passed the ciliate cell, was killed in the process, but could not be vacuolized. One consistent difference between the two ciliates is noteworthy: Dileptus never accepted any ciliate prey, nor Algae, while Stentor ingested repeatedly both types of resource.

Both ciliates must be categorized as omnivores, firstly, because they ingest plants and animals (Fungi, Protozoa and Rotifera), and secondly, because they feed on various trophic levels: Thecamoebae and rotifers feed on fungi (Walker 1987), and unicellular algae are a normal resource of Protozoa and Rotifera.
The same criteria of omnivory are valid for the platyhelminth Stenostomum sp., which accepts largely the same reource types as the two ciliates, and - owing to its larger size - also catches a variety of microcrustacea.

\section{ODONATA (TAB. 2)}

Both species, Ischneura sp and Aeschnosoma sp are essentially insectivores, which is the rule for Odonata larvae, any other prey type is sporadic. The only exception is oligochaete capture by Aeschnosoma. The Anisoptera occupy niches within the litter layers, and thus, have access to the small oligochaetes that colonize the surface of litter leaves, while the Zygoptera usually occupy surfaces near the open water, where oligochetes are less frequent. The prevalent prey of both Odonata species are Ephemeroptera and Chironomidae, presumably because these are the most frequent and ubiquitious insect larvae in these benthic habitats (Walker 1994, 1998). Algae ingestion is questionable, because small algae may accidentally enter the ventricle in the course of prey capture. Rather surprizing are fish vertebrae within an Odonata ventricle, yet, the smallest fish species of the litter habitat is a tiny gobby Microphylipnus, with a standard length of $1,2 \mathrm{~cm}$. This fish, therefore, is within the range of the normal prey of larger anisopteran larvae, furthermore, there are the larvae and juveniles of other small litter-colonizing fish species, which may serve as prey.

On the whole it appears that both Odonata species, although belonging to two different Suborders, accept any animal prey within the range of their perception and size that allows for successful capture and ingestion. Thus, even if algae- feeding is excluded, they are omnivores in the sense that they feed on various trophic levels, considering that larger insect larvae (Ephemeroptera, Trichoptera) feed on algae, microcrustacea and chironomids (Walker 1987).

FISH (TAB. 3)

Although relatively few individuals in each species were available for dissection, the general situation indicates that all these small fish species, mostly associated with litter deposits and with marginal vegetation in shallow waters, are true omnivores in the sense that they ingest plants and animals, and they also feed on various carnivorous trophic levels, as shown by the wide spectrum of resource utilization, which ranges from 12 (Nemuroglanis) to 18 (Apistogramma) resource types as listed in Tab.3.

Cladocera and the larvae of Chironomids (including the predatory Tanypodinae) and of Ephemeroptera are the prevalent prey types, again, as argued for the case of the Odonata, because these prey organisms have the highest population densities in the benthic habitat of submerged litter (Walker 1987, 1994). Cladocera input is not the passive result of periphyton scraping, if this were the case, peripyton- feeding would be more frequent than Cladocera ingestion. Also, of 
the 10 Hyphessobrycon with Cladocera in their stomachs, two had ingested more than 100 such prey individuals. This indicates that microcrustaceans are picked one-by-one from the litter leaves and from the periphyton adhering to roots and to submerged branches, a typical behaviour of fish browsing that I observed frequently in the natural habitat.

The single incidence of detritus-feeding refers to an individual of Apistogramma. cf regani, with half of its stomach filled with tree bark of intensely orange colour, probably due to $\mathrm{Fe}^{3}$-excreting bacteria, as known from Leptothrix ochracea, (Chlamydobacteriales; Strasburger et al 1978).

\section{DECAPODA (TAB.4)}

In the shrimps, herbivory and carnivory are equally important. Combined ingestion of unidentifyable plantmaterial, of algae and fungi indicates that they may be true shredders of submerged litter in an advanced stage of decomposition, when decomposition fungi are massively colonizing the leaves. The algae of this habitat are mostly benthic diatoms which settle on the litter leaves, as do thecamoebae, small oligochaetes, mites (Acarina) and the tardigrades. In addition, shrimps are true predators, which catch and ingest mobile prey organisms, as indicated by the high frequency of cladocere and beetle (Coleoptera) ingestion for example. Interesting is the capture of adult ants - that presumably were floating on the water surface - by 10 individuals of $M$. inpa. This indicates that truly benthic shrimp species also operate near the water surface. The size of the vertebrae of the three captured fish suggests that these were either larvae or else, individuals of Microphylipnus sp, the smallest species of the Amazonian benthic habitats (standard length ca $12 \mathrm{~mm}$ ).

\section{CONCLUSIONS AND DISCUSSION}

\section{GENERAL OMNIVORY}

The data presented in Tables 1-4 show conclusively that the benthic macro-fauna of Central Amazonian blackwater streams, as well as the microfauna associated with submerged litter and water plants, is essentially omnivorous: From Protozoa to shrimps and fish, the consumers feed on various trophic levels which - with the possible exception of the Odonata larvae - include plants and animals. The length of foodchains is impressive, particularly for Protozoa, which, for instance, places the ciliate Dileptus cf. anser on the $4^{\text {th }}$ trophic level: Bacteria Vampyrellidae (Rhizopoda) Arcella (Thecamoebae) Dileptus, not to mention that this unicellular predator feeds on metazoa with a complex anatomy (Rotifera). The longest possible foodchain of the small benthic fish species includes: Algae/periphyton microcrustacea Chironomidae Trichoptera smallest fish Odonata larger fish, thus placing the fish on the $7^{\text {th }}$ trophic level. However, as the fish feed on all these lower levels, the different possible, and actually realized food chains are generally shorter. An interesting detail refers to the two species Elachocharax pulcher and Apistogramma cf regani: In the foodweb analysed for a single meander of the stream Tarumã- Mirím (Henderson \& Walker 1986), these two species were also relatively frequent, and resource similarity between these two species was $60 \%$, as against only $45,5 \%$ in Tab.3 (with the fish taken in different rivers). This indicates that the prey incidentially present is more determinative than prey choice by the fish.

The ornamental fish Paracheirodon axelrodi (Characidae), the "Cardinal Tetra", which colonizes the floodplains of some rivers of the middle Rio Negro Basin, shows a similar feeding pattern as the fish species of this study (Tab.3): more than $40 \%$ of the cardinals ingest microcrustacea and chironomids, however, ingestion of algae and detritus is more frequent in the cardinal (Walker 2004). The remarkable similarity of the fish- and shrimp resource-spectra implies that foodchains are largely similar in the two predator categories.

On the whole, the general resource spectrum of the six small, benthic fish species collected in Rio Negro tributaries (Tab. 3) is concordant with the results published by Goulding et al (1988) for a total of 450 Rio Negro species: Omnivory is the prevalent feature, but feeding on plant matter is more common in these Rio Negro fish than suggested by the data in the present paper. The major invertebrate prey types of the Rio Negro fish species are micro-crustacea and insects, chironomid larvae being the most frequent insect prey. Detritus ingestion is common in the Rio Negro fish, however, this may partly be due to differences of method: Goulding et al (1988) listed the material found in the whole intestine, while the results in Table 3 refer only to stomach content.

Long-term observation of feeding behaviour in the course of development (Leite and Araújo-Lima 2002) and/ or during the annual inundation cycles may reveal switching of feeding strategies, as suggested by a recent study of the Cardinal Tetra (Paracheirodon axelrodi, Marshall 2004). This temporal variation amplifies the food spectrum in sample series of the respective fish species, and may have some effect on the fish diets presented in Tab. 3, because smallest and largest within-species-size of these fish varies by a factor of 1.5 - 3.0, i.e. includes younger and older individuals. The relative small number of specimens dissected of each species, does - however - not allow to ascertain age-dependent prey choice. Certain is, that predation prevails over herbivory, and this may be particularly important for the fauna of the mineral-poor Rio Negro waters. Carnivory means primarily ingestion of proteins, and proteins include relatively high levels of all the vital chemical elements for the reproduction and maintenance of animals. 
The same argument is valid for fungus-feeding, which is important for the benthic fauna of the poor Rio Negro waters (Walker 1985, 1987): 57 invertebrate species, ranging from protozoans to shrimps, and including the major prey of fish (Chironomidae, Ephemeroptera), were shown to ingest spores and/or hyphae of the litter-decomposing aquatic fungi. Indeed, it is probably the high frequency of fungus-feeding, combined with general omnivory in the benthic fauna of mineral-poor Amazonian waters, that results in apparently questionable interpretation of the various data on the origin of the energy input of the fishes of the Rio Negro Basin as determined by carbon- isotope analysis of their tissues (Forsberg et al 1993, Furch \& Junk 1997, Thomé de Souza 2005): low values of ${ }^{13} \mathrm{C}$ - isotopes in fish tissues indicate phytoplankton and periphyton as primary resource input, while higher values result from forest input (mainly fungi that decompose submerged leaf litter and dead wood). The major resources of omnivore fish that are collected in river channels, in the free water and along sun-lit river margins are algae, periphyton, microcrustacea and insect larvae, while the same fish species may depend on the fungi that decompose submerged litter leaves and dead wood as resource input in forest streams and in the inundation forest. Alternative feeding would result in intermediate isotope values. As a matter of fact, the complexity of the foodwebs of omnivores means, that carbon-isotope analysis is probably the only conclusive method as regards the primary energy input of the fish and shrimps from poor Rio Negro waters, and that these values are a function of the actual feeding grounds of the fish. The potential importance of fungus ingestion by the major prey of fish in the Rio Negro river system is shown in Tab. 5. The data refer to the analysis of the stomach contents of 50 fish species collected along the Rio Negro channel (Thomé de Souza 2005), major prey organisms being Chironomidae, Ephemeroptera, Trichoptera and zooplankton. These fish species do not include Characidae and Cichlidae (that is, the consumer fish presented in Tab.3).

Specially noteworthy features of the data (Tab. 1 - 4) are firstly, the wide spectrum of resource utilization within species, and secondly, the wide overlap of resource utilization between species, be they vertebrates or invertebrates. Thus - excluding detritus and unspecified plant material - 20 of the 25 resource types listed for the fish (Tab. 3) are utilized by two or more species, and 19 of the 22 shrimp resource types (Tab. 4) are shared between several species. Resource similarity between the fish and shrimps (Tab. 3 and 4) is 64\%. Thereby it is important to note that all of these species are associated with the same habitats: primarily benthic litter accumulations and - to a minor extent - submerged, marginal vegetation. Thus, any two shrimp species in Tab.4 may be caught in the same net sample. A special feature is "reciprocal feeding" between odonata larvae, fish and shrimps, the larger individuals feeding on smaller individuals of the other two types. This implies that the relative size between predator and prey, rather than prey species, is the decisive factor that determines prey choice, an observation also made by Woodward (2001) with regard to the foodweb of an English stream. A wide overlap of the diets of fish, shrimps and larger insects is also recorded from a Southern Chinese stream (Mantel et al 2004). Omnivory thus applies in its widest sense: everything that can mechanically be tackled and is physiologically acceptable (i.e. is neither toxic nor irritating) is ingested.That is, acceptance is general and rejection is specific. Havens et al. (1996) studying the foodweb of a Florida lake, arrive at similar conclusions: "Most consumers were omnivorous".

With regard to ecosystem analysis, this pattern of general omnivory is important: the resource spectrum of the consumers is representative for the species composition in this habitat, whereas - in specified omnivory, the resource spectrum of the consumers is representative for species-specific resource selection.

\section{STABILIZATION OF BIODIVERSITY?}

The situation of "general omnivory" within a limited ecosystem evokes the problems of "diversity and stability, because - if all consumers are feeding on most of the different resources, there are no separate food niches for the different consumers, and unlimited resource competition would result in irregular and excessive population fluctuations and would drive the weaker species to extinction. However, this is true then only, if resources are truly limiting. If space is limiting, then omnivory implies resource redundancy: if one resource species becomes scarce, consumers feed more heavily on other species, and this allows the declining species to recover. Hence: the more diversity, the more resource redundancy and the more stability. Ecological reality seems to be more in tune with this type of system: For the benthic fauna of the TarumáMirím, there is convincing evidence that space- rather than resource- is limiting. Relative standing-stock densities between predators and prey in the benthic litter habitat are relatively stable, and potential prey individuals available per predator is usually >100 and never drops to below 50 (Walker 1994, Walker et al 1991). Indeed, space limitation may be a common feature of aquatic faunas: thus Maltchik and Pedro (2000) showed a positive relation between biodiversity and stability in the communities of shallow lakes, and Schmid-Abraya et al (2002), analysing the foodweb of an acid stream, conclude that the dense web-connectance provides alternative energy pathways for the top-predators, with a stabilizing effect on the energy flow through the system.

The range of resource data presented in this study would thus support the conclusion, that within the context of Amazonian biodiversity and system stability, general omnivory in the benthic habitats of nutrient-poor Rio Negro waters 
Table 5 - The potential importance of litter- decomposing fungi as energy input for Rio Negro fish species. A: Percent (\%) fish species that ingested the respective prey types ( $100 \%=50$ species). Prey relevance: Percent fish species with at least $10 \%$ of individuals that ingested the respective prey (after Thomé de Souza, 2005). B: Fungus- feeding by the prey types of the fish. $n=$ total number of prey species and individuals respectively, examined. $x=$ number of species and of individuals (sum of all species) that ingested aquatic fungi. * Zooplankton in B refers to 20 species of Thecamoebae only (after Walker 1987).

\begin{tabular}{|c|c|c|c|c|c|c|c|c|c|}
\hline \multirow{2}{*}{\multicolumn{2}{|c|}{ Prey acceptance by fish }} & \multicolumn{8}{|c|}{ Prey types of fish } \\
\hline & & \multirow{2}{*}{\multicolumn{2}{|c|}{$\begin{array}{c}\text { Chironomidae } \\
64 \%\end{array}$}} & \multirow{2}{*}{\multicolumn{2}{|c|}{$\begin{array}{c}\text { Ephemeroptera } \\
36 \%\end{array}$}} & \multirow{2}{*}{\multicolumn{2}{|c|}{$\begin{array}{c}\text { Trichoptera } \\
28 \%\end{array}$}} & \multirow{2}{*}{\multicolumn{2}{|c|}{$\begin{array}{c}\text { Zooplankton } \\
28 \%\end{array}$}} \\
\hline \multirow{2}{*}{ A } & Fish species (\%) & & & & & & & & \\
\hline & Prey relevance & \multicolumn{2}{|c|}{$44 \%$} & \multicolumn{2}{|c|}{$26 \%$} & \multicolumn{2}{|c|}{$18 \%$} & \multicolumn{2}{|c|}{$6 \%$} \\
\hline \multirow{4}{*}{ B } & Fungus feeding & $x$ & $n$ & $x$ & $\mathrm{n}$ & $x$ & $\mathrm{n}$ & ${ }^{\star} x$ & ${ }^{*} n$ \\
\hline & by prey species (nrs) & 5 & 6 & 2 & 3 & 4 & 5 & 18 & 20 \\
\hline & by individuals (nrs) & 27 & 36 & 24 & 34 & 11 & 24 & 67 & 75 \\
\hline & $=\%$ & \multicolumn{2}{|c|}{75,0} & \multicolumn{2}{|c|}{70,6} & \multicolumn{2}{|c|}{45,8} & \multicolumn{2}{|c|}{89,3} \\
\hline
\end{tabular}

essentially contributes to the stabilization of the ecosystem and its biodiversity.

\section{ACKNOWLEDGEMENTS}

I am thanking Prof. Dr. Ning Labish Shao (University Federal of the Amazonas) for the identification of the fish, and Dr. Regina Oliveira da Silva (Muséu Goeldi, Belém) for the identification of the Odonata larvae, and Dr. Matthias Wantzen (University of Konstanz, GE) for helpful comments and suggestions.

\section{LITERATURE REFERENCES}

Arthington, A. H. 1992. Diets and trophic guild structure of freswater fishes in Brisbane streams. Proc. Royal Soc. of Queensland 102: 31 - 47.

Chauvel, A., Y. Lucas and R. Boulet. 1987. On the genesis of the soil mantle of the region of Manaus, Central Amazonia, Brazil. Experientia 43/3: 234-240.

Evans-White, M., W.K. Dotts, L.J. Grey and K. M. Fritz. 2001. A Comparison of the trophic ecology of the crayfishes Orconectes nais (Faxon) and Orconectes neglectus (Faxon) and the central stoneroller minnow Campostoma anomalum (Rafinesque): Omnivory in a tallgrass prairie stream. Hydrobiologia 462: 131-144.

Forsberg, B. R., C. A. Araújo- Lima, L. M. Martinelli, R. L. Vitória, J. A. Bonassi 1993. Autotrophic carbon sources for fish of the Central Amazon. Ecology 74: 643 - 652.

Furch, K. and W. J. Junk. 1997. The chemical composition, food value and decomposition of herbaceous plants, leaves and leaf litter of the floodplain forests. In: Junk, W. J. (ed). The Central Amazon floodplain ecology of a pulsing system. Ecological Studies 126, pp. 187 - 205 Springer Verlag, Berlin.

Goulding, M., M. Leal-Carvalho and E.G. Ferreira. 1988. Rio Negro, rich life in poor water. SPB Academic Publishing, The Hague, 172pp.
Havens, K.E., L.A. Bull, G.L. Warren, T.L. Crisman, E.J. Philips and J.P. Smith.1996 foodweb structure in a subtropical lake ecosystem. Oikos 75: 20-32.

Henderson, P.A. and I. Walker 1986. Of the leaf litter community of the Amazonian blackwater stream Tarumãzinho. J. Trop. Ecol. 2: 1-17.

Kensley, B. and I. Walker. 1982. Palaemonid shrimps from the Amazon Basin, Brasil (Crustacea: Decapoda, Natantia). Smithsonian Institution Press, Washington.28pp.

Leite, R.G. and C.A. Araujo-Lima. 2002. Feeding of the Brycon cephalus, Triportheus elongatus and Semaprochilodus insignis (Osteichthyes, Characiformes) larvae in Solimões - Amazonas floodplain areas. Acta Amazônica 32(3): 499-516.

Lancaster, J. and Robertson, A. L. (1995). Microcrustacean prey and macroinvertebrate predators in a stream foodweb. Freshwater Biology 34/1: 123 - 134

Maltschik, L. and F. Pedro. 2000. Biodiversity influences community stability? Results of semiarid shallow lakes. Ciência e Cultura J. Braz. Assoc. Adv. Sci. 52/2: 127-130.

Mantel, S.K., M. Salas and D.Dudgeon. 2004. Foodweb structure in an tropical Asian forest stream. J. N. Am. Benthol. Soc. 23(4): 728-755.

Marshall, B.2004. Fontes autotróficas de energia para Paracheirodon axelrodi (Osteichthyes, Characidae) na bacia do médio Rio Negro. M.Sc. Thesis, INPA, Manaus.

Methvin, B.R. and K. Suberkropp. 2003. Annual production of leaf-decaying fungi in two streams. J. N. Am. Benthol. Soc. 22(4): 554-564.

Motta- Bührnheim, C.M. and C. Cox- Fernandez. 2003. Structure of fish assemblages in Amazonian rain- forest streams: Effects of habitats and locality. Copeia 2: 255-262.

Padgett, D.E. 1976. Leaf decomposition by fungi in a tropical rain forest stream. Biotropica 8(3): 166-178

Parkyn, S. M., K. J. Collier and B. J. Hicks. 2001. New Zealand stream crayfish: Functional omnivores but trophic predators? Freswater Biology 46(5): 641-652. 
Pimm, S.L. 1991. The balance of nature. The University of Chicago Press. Chicago and London. 434pp.

Pimm, S.L. and J.H. Lawton 1977. On the number of trophic levels. Nature 268: 329-331.

Pringle, C. M. and T. Hamazaki, 1998. The role of omnivory in a neotropical stream. Ecology 79/1: 269 - 280.

Reis, R.E., S.O. Kullander and C.J. Ferraris Jr. 2003. Checklist of the freshwater fishes of South- and Central America. EDIPUCRS Porto Allegre, Brazil, 729pp.

Schmid-Abraya, J.M., A.G. Hildrew, P.E. Schmid and J. Winterbottom. 2002. The importance of meiafauna in foodwebs: evidence from an acid stream. Ecology 83/5: 1271-1285.

Sioli, H. 1984. The Amazon: Limnology and landscape ecology of a mighty tropical river and its basin. Monographiae biologicae 56. Dr. W. Junk Publ. Dordrecht, Boston, Lancaster.

Strasburger, E., F. Noll, H. Schenk and A.F. Schimper .1978. Lehrbuch der Botanik. Gustav Fischer Verlag, Stuttgart, New York. 31.Ed.,1078pp.

Thomé de Souza, M. J. 2005. Fontes autotróficas de energia para os peixes do canal principal e quelônios do médio Rio Negro (Amazônia, Brasil). Ph.D. Thesis, INPA/FUA, Manaus (Amazonas, Brazil).

Usio, N., and C.R. Townsend. 2002. Functional significance of crayfish in stream foodwebs: Roles of omnivory, substrate heterogeneity and sex.. Oikos 98(3): 512-522.

Walker, I. 1978. Rede de alimentação de invertebrados das águas pretas do sistema Rio Negro. Observações sobre a predação de uma Amoeba do tipo Amoeba discoides. Acta Amazônica 8/3: 423-438.

Walker, I. 1985. On the structure and ecology of the micro-fauna in the Central Amazonian forest stream "Igarapé da Cachoeira". Hydrobiologia 122: 137 - 152.

Walker, I. 1987. The biology of streams as part of Amazonian forest ecology. Experiencia 43: 279-287.
Walker, I. 1988. Study of benthic micro-faunal colonization of submerged litter leaves in the Central Amazonian blackwater stream Tarumã-Mirím (Tarumãzinho). Acta Limnol. Brasil. 11: 623-648.

Walker, I. 1994. The benthic litter-dwelling macrofauna of the Amazonian forest stream Tarumã- Mirím: patterns of colonization and their implications for community stability.. Hydrobiologia 291: 75-92.

Walker, I. 1995. Amazonian streams and small rivers. In: J.G. Tundisi, C.E. Bicudo and T. Matsumura-Tundisi eds: Limnology in Brazil. ABC/SBL, Rio de Janeiro, pp. 167 - 194.

Walker, I. 1998. Population dynamics of Chironomidae (Diptera) In the Central Amazonian blackwater river Tarumã- Mirím (Amazonas, Brazil). In: J.L. Nessimian \& A.L. Carvalho eds: Ecologia de insetos aquáticos. Oecologia Brasiliensis 5: 235252.

Walker, I. 2003. The benthic insect fauna of the blackwater forest stream Tarumã-Mirím (Manaus, Amazonas): Patterns of population dynamics and their implications for ecosystem stability. Amazoniana 17, 3/4: 47-480.

Walker, I. 2004. The food spectrum of the cardinal- tetra (Paracheirodon axelrodi, Characidae) in its natural habitat. Acta Amazonica 34/1: 69-73.

Walker, I., P.A. Henderson and P. Sterry. 1991. On the patterns o biomass transfer in the benthic fauna of an Amazonian blackwater river, as evidenced by ${ }^{32} \mathrm{P}$ label experiment. Hydrobiologia 215: 153-162.

Woodward, G. and A. G. Hildrew. 2001. Invasion of a stream foodweb by a new top predator. J. Animal Ecology 70(2): 273-288.

Recebido em 27/11/2007

Aceito em 26/05/2009 